\title{
Tree Species Distribution along Environmental Gradients in an Area Affected by a Hydroelectric Dam in Southern Amazonia
}

\author{
Pamela Moser ${ }^{1}$, Washington L. Oliveira ${ }^{2}$, Marcelo B. Medeiros ${ }^{3,5}$, José R. Pinto ${ }^{1}$, Pedro V. Eisenlohr ${ }^{4}$, Isabela L. Lima ${ }^{2}$, \\ Glocimar P. Silva ${ }^{3}$, and Marcelo F. Simon ${ }^{3}$ \\ ${ }^{1}$ Departamento de Engenharia Florestal, Universidade de Brasilia, Campus Universitário Darcy Ribeiro, Brasillia, DF. C.P. 4357. 70910-900, \\ Brazil \\ ${ }^{2}$ Departamento de Ecologia, Universidade de Brasilia, Campus Universitário Darcy Ribeiro, Brasılia, DF 70910-900, Brazil \\ ${ }^{3}$ Embrapa Recursos Genéticos e Biotecnologia, Parque Estação Biológica, Av. W5 Norte, Brasilia, DF 70770-917, Brazil \\ ${ }^{4}$ Departamento de Botânica, Universidade Federal de Minas Gerais, Av. Presidente Antônio Carlos, 6627, Pampulha, Belo Horizonte, MG \\ 31270-901, Brazil
}

\section{ABSTRACT}

We describe the patterns of composition and abundance of tree species and their relationships to environmental factors in an area affected by the Jirau hydroelectric dam on the Madeira River in the Brazilian state of Rondônia. Trees were sampled in 20 1-ha forest plots distributed among areas affected and unaffected by the hydroelectric reservoir. Predictors of species distribution included in the analyses were soil fertility (sum of bases) and texture, slope, and the vertical distance from the nearest drainage. We sampled 8504 individuals belonging to 909 species/morphospecies. Floristic differences occurred throughout the reservoir area and between the sides of the river, and were strongly associated with edaphic and geological factors. The predictor with the greatest effect on the floristic changes was the sum of bases, coupled with the vertical distance from the nearest drainage, the latter reflecting the influence of the riparian zone. The forests sampled were heterogeneous and included transitional formations between unflooded terra firme and seasonally inundated (varzea, campinarana) forests. Although a considerable number of species (253) were restricted to plots affected by the reservoir, most of these species have a widespread distribution in the Amazon region. However, conservation measures are required in order to preserve species associations and ecosystems processes similar to those most affected by the reservoir such as the river floodplains. Our study reinforces the need to consider the heterogeneity of habitats affected by reservoirs when making decisions concerning the building of hydroelectric dams in the Amazon.

Abstract in Portuguese is available in the online version of this article.

Key words: environmental gradients; Madeira River; open rain forests; riparian zones; soils.

IN THE AMAZON BASIN, FLORISTIC PATTERNS have been related both to intrinsic factors, such as dispersal limitation and biotic interactions, and extrinsic ones, such as the environment (Terborgh \& Andresen 1998, Condit et al. 2002, Pitman et al. 2008, Dexter et al. 2012). A large set of soil and topographic factors are considered important predictors of floristic patterns at different spatial scales (Phillips et al. 2003, ter steege et al. 2006, Ruokolainen et al. 2007, Coronado et al. 2009, Zuquim et al. 2012). The diversity of these environmental predictors in Amazonia can be associated with geomorphological and geological differences that occur along the basin (Quesada et al. 2010, Higgins et al. 2011).

The influence of soil on floristic variation in the Amazon basin has been investigated in detail in the western, central, and northern regions. In the western portion, the physical and chemical properties of the soil, such as the concentrations of calcium $(\mathrm{Ca})$, magnesium $(\mathrm{Mg})$, potassium $(\mathrm{K})$, sodium $(\mathrm{Na})$, and phosphorus $(\mathrm{P})$ cations, are considered the main determinants of

Received 6 December 2013; revision accepted 17 February 2014.

${ }^{5}$ Corresponding author; e-mail: marcelo.brilhante@embrapa.br species distributions (Tuomisto et al. 2002, Phillips et al. 2003, Pitman et al. 2008, Higgins et al. 2011). Younger and nutrient-rich soils of Andean origin in this region (Quesada et al. 2010) support distinct tree communities from those that occur on the east side of the basin, which usually grow in older and poorer soils formed by cratonic sediments (Terborgh \& Andresen 1998, Pitman et al. 2008, Coronado et al. 2009). In central and northern Amazonia, topography and soil variables, such as clay content, have been considered the main predictors of plant species distribution (Costa et al. 2005, Kinupp \& Magnusson 2005, Zuquim et al. 2012, Pansonato et al. 2013). With respect to elevation and slope, topography is not a causal factor itself, but it produces gradients in water availability, soil texture and fertility, and light availability, which can influence the composition of plant communities depending on the ecological preferences of individual species (e.g., Costa et al. 2005).

Riparian zones exhibit remarkably different patterns of floristic composition in Amazonia compared to terra firme forests (Ferreira \& Prance 1998, Ferreira 2000, Drucker et al. 2008). Communities of flood-tolerant flora are typically determined by 
the depth of the water table and light regime associated with major rivers in the Amazon. In addition, forest areas adjacent to Amazonian rivers are often influenced by the seasonal deposition of sediments, such that species composition is strongly associated with fertility patterns related to sediment source material (Quesada et al. 2010).

Although the importance of soil fertility, texture, and topography as predictors of species composition and abundance in Amazonian forests has been widely documented, there are few studies addressing floristic patterns in many parts of the basin, particularly in southern Amazonia (ter Steege et al. 2013). This is a major concern for the conservation of the region because human impacts, including deforestation for intensive agricultural activities and the construction of large hydroelectric dams (particularly on the Madeira River; Finer \& Jenkins 2012), have been significant in recent decades (Ferraz et al. 2005).

We investigated if tree assemblages were affected by the Jirau hydroelectric (UHE Jirau) reservoir located on the middle Madeira River in the southern Amazon. Our study area stretches for $80 \mathrm{~km}$ around the dam and includes open rain forest plots representing, at the mesoscale, the compositional and environmental variation in the area affected by the UHE Jirau reservoir. We focus on the following questions: (1) how are tree species distributed with respect to their occurrence and abundance in communities and with respect to their association with the environment? (2) Are there compositional differences between areas that will be affected and unaffected by the UHE Jirau reservoir, and what are the implications of such differences for biological conservation? (3) How does the hierarchical structure of environmental gradients of soil variables, topography and height above the nearest drainage (a proxy for the depth of the water table) influence floristic patterns?

\section{METHODS}

Study area.-We conducted the study in the municipality of Porto Velho, Rondonia, in southern Amazonia, in the area of the UHE Jirau reservoir, in the basin of the Madeira River (Fig. S1). The UHE Jirau was designed as a 'run-of-the-river' hydroelectric type that requires little water storage and has a reduced reservoir size compared to traditional hydroelectric dams. However, its operation will involve a seasonal rise in the river level, estimated to vary between $82.5 \mathrm{~m}$ (dry season) and $90 \mathrm{~m}$ (rainy season), which is approximately $5-10 \mathrm{~m}$ above the pre-damming levels of the river and will cause both permanent and temporary flooding in forest areas surrounding the reservoir. Another hydroelectric dam (UHE Santo Antonio) of comparable size is located approximately $100 \mathrm{~km}$ downstream on the Madeira River, and two additional dams are planned upstream (Fearnside 2013).

The predominant vegetation type of the region is lowland open rain forest (IBGE 2004), characterized in most of the area as an open canopy terra firme forest due to the lack of flooding during the rainy period (Pires \& Prance 1985). Other vegetation types in the region include patches of woody campinarana, a seasonal low-stature forest subject to flooding during the rainy sea- son caused by the rise of the water table, as well as narrow strips of varzea forests (areas that are seasonally inundated by the rise of the Madeira River and its tributaries). Transitional areas between terra firme forest, campinarana, and varzea forests also occur in the region. Typical varzea areas are not extensive in the study area because the seasonally flooded area of the Madeira River is not wide relative to the seasonally flooded areas of other large rivers in the Amazon basin.

The climate in the study area is tropical humid and hyperthermic (Cochrane \& Cochrane 2010), with the highest average annual temperature ranging from $31-33^{\circ} \mathrm{C}$, the lowest annual temperature ranging from $20-22^{\circ} \mathrm{C}$, and the annual precipitation ranging from 1700 to $2000 \mathrm{~mm}$ (INMET 2013). The elevation in the region varies between 70 and $358 \mathrm{~m}$ asl (Fig. S1). The predominant soils in the study area are Acrisols and Ferralsols (latosols), mainly in the open rain forest on the left side (when facing downstream) of the Madeira River. Hydromorphic Gleysols also occur, but are more common in transition areas of the woody campinarana forest (Cochrane \& Cochrane 2010, Santos et al. 2011) located at right side of the Madeira River. Fluvisols formed by alluvial sediment deposition occur at the margins of the Madeira River.

The right side of the river reflects a more recent geological formation (Cenozoic period) with past alluvial deposits corresponding to Gleysol areas on flatter terrain. On the left side, older geological formations of the Proterozoic predominate, with post-orogenic granitoids (CPRM 2004) and a more hilly landscape. The right side of the Madeira River has a history of land use and occupation, mainly due to farms that were founded as a result of the construction and subsequent pavement of the BR364 highway during the 1980s (Ferraz et al. 2005). The area on the left side of the river is more conserved and includes the Mapinguari National Park.

Data COllection: Vegetation COMPOSition AND STRUCtURE.Our sampling was conducted in 2010 before the UHE Jirau reservoir was filled. We systematically distributed RAPELD sampling modules (Magnusson et al. 2005) perpendicular to the Madeira River, with two modules next to the hydroelectric dam (Caiçara), two modules in the intermediate portion (Mutum) and two in the final portion (Abunã) of the future UHE Jirau reservoir. Each module was formed by two transects, and the longest distance between modules was $80 \mathrm{~km}$. We allocated permanent plots along transects: nine plots in Caiçara, four in Mutum and seven in Abunã. The minimum distance between plots was $1 \mathrm{~km}$. In total, 11 plots were in areas that will be subject to the reservoir flooding and nine plots in areas that will not be directly affected (Fig. S1). Most of the area affected by the UHE Jirau reservoir is located on the right side of the river near the dam (including the Caiçara T4 module) and along the margins of the Madeira River (including P1 plots in all transects; Fig. S1).

We allocated the plots only in open rain forest areas, including terra firme forests and transitional areas between this vegetation type and varzea forests or campinaranas. The distribution of the plots in modules depended on accessibility, which was limited 
by the rugged relief on the left side of the river and by the occurrence of campinarana patches (not considered in this study) on the right side in the intermediate portion of the reservoir (Mutum), restricting plots to locations nearest the river at this sampling site. Plot elevation ranged from 86-116 $\mathrm{m}$ asl. Additional information on study sites is provided in Table 1.

Following the RAPELD protocol (Magnusson et al. 2005), the allocation of plots followed the contour of the terrain to minimize internal variation in topography and soil and to allow the use of these variables as predictors of species distribution. In each 1-ha $(250 \times 40 \mathrm{~m})$ plot, we sampled all trees that were $\geq 30 \mathrm{~cm}$ in diameter at breast height (dbh), $1.30 \mathrm{~m}$ above the ground. We subsampled trees with a diameter between $10 \mathrm{~cm} \leq \mathrm{dbh}<30 \mathrm{~cm}$ in 0.5 -ha $(20 \times 250 \mathrm{~m})$ plots and trees between $1 \mathrm{~cm} \leq \mathrm{dbh}<10 \mathrm{~cm}$ in 0.05 -ha $(2 \times 250 \mathrm{~m})$ plots. In total, we sampled 20 plots with areas of 20, 10 and 1 hectare for each diameter class.

Identifications were performed in the field by taxonomists and parataxonomists with the aid of identification guides (Henderson et al. 1995, Ribeiro et al. 1999, Wittmann et al. 2010). We collected voucher specimens of at least one individual of each species surveyed for further identification in the Embrapa Recursos Genéticos e Biotecnologia (CEN) herbarium. We identified voucher specimens to the species level (or as morphospecies); for some groups we were able to conform identifications with experts (i.e., Burseraceae: D. Daly; Lecythidaceae: S. Mori; Melastomataceae: F. Michelangeli). Plant identifications also benefited from the experience accumulated by the authors during an extensive floristic survey carried out in the UHE Jirau region from 2008-2013. Vouchers were deposited in the herbarium of Embrapa Genetic Resources and Biotechnology (CEN), and duplicates were sent to the following herbaria: Federal University of Acre (UFACPZ), Federal University of Rondônia (RON), National Institute for Amazonian Research (INPA), New York Botanical Garden (NY), Rio de Janeiro Botanical Garden (RB), and the Embrapa Amazônia Oriental (IAN).

Data COllection: EnVironmental DATA.-We considered four environmental factors that are recognized as important predictors for plant distribution patterns in Amazonia: soil fertility and texture, slope and vertical height relative to the nearest river (Costa et al. 2009, Zuquim et al. 2012, Figueiredo et al. 2013, Pansonato et al. 2013, Schietti et al. 2013). Climate is also an important factor (Coronado et al. 2009, Toledo et al. 2011) but was not included because the variation is not relevant in the scale of the study. We collected soil samples at six locations within each plot $(0,50,100,150,200$, and $250 \mathrm{~m})$ and at four depths $(0-5,5-10$, 10-20, 20-30 cm), totaling 24 single samples per plot. Samples were dried at room temperature and aggregated within each depth range for physical and chemical analysis. Soil variables were summarized in the analyses by a plot average of sum of exchangeable bases $\left(\mathrm{Ca}^{+2}, \mathrm{~K}^{+}, \mathrm{Mg}^{+2}, \mathrm{Na}^{+}\right)$and soil texture (clay content is commonly used in other studies and was chosen as predictor because it was correlated with PCA axes of the soil textural parameters). Although a large number of soil parameters were available, we decided to use only two of them to reduce the number of predictive variables in our analysis. These two parameters have been shown to be strong predictors of floristic patterns in the Amazon (e.g., Pansonato et al. 2013). The slope of the terrain in each plot was measured using a PM-5/360 Suunto clinometer (Suunto, Finland) through five steps every $50 \mathrm{~m}$, perpendicular to the central axis.

Elevation data were obtained using an airborne laser sensor with a laser point cloud density obtained with 3 points $/ \mathrm{m}^{2}$ and were provided by the Energia Sustentável do Brasil. We interpolated these data using a Digital Terrain Model (DTM) in geotiff format with a resolution of $5 \mathrm{~m}$. We obtained the height above the nearest drainage (HAND) from the altitudinal difference between the nearest drainage and elevation of each plot, using a DTM. We used the HAND variable considering its high correlation with the depth of the water table and influence on water availability for plant communities (Nobre et al. 2011, Schietti et al. 2013).

DATA ANALYSIS. - We standardized species abundance data by the total number of individuals in each plot and calculated the BrayCurtis index (quantitative dissimilarity matrix). Species occurrence

TABLE 1. Minimum, maximum, and average values for environmental variables in the forest plots of Abuna (final portion of the reservoir), Mutum (intermediate portion) and Caiçara (near the dam), in the area of the Jiran bydroelectric reservoir.

\begin{tabular}{|c|c|c|c|c|c|}
\hline Areas & Number of Plots & Sum of bases $\left(\mathrm{cmol} / \mathrm{dm}^{3}\right)$ & Clay content $(\%)$ & Slope (degrees) & HAND (m) \\
\hline \multicolumn{6}{|l|}{ Abunã } \\
\hline Min.-Max & 7 & $4.72-5.81$ & $17.50-47.50$ & $0.1-8$ & $12.78-34.28$ \\
\hline \multicolumn{6}{|l|}{ Mutum } \\
\hline Min.-Max & 4 & $1.12-10.74$ & $31.25-41.88$ & $1.2-6$ & $11.08-14.47$ \\
\hline Min.-Max & 9 & $0.37-0.76$ & $25.63-68.75$ & $0.5-10.2$ & $10.74-27.65$ \\
\hline Average $\pm \mathrm{SD}$ & & $0.55 \pm 0.12$ & $46.39 \pm 17.45$ & $3.0 \pm 2.94$ & $17.67 \pm 6.53$ \\
\hline
\end{tabular}

SD, standard deviation. 
data (presence/absence) were analyzed using the Sorensen index (qualitative similarity matrix). We used Principal Coordinates Analysis (PCoA) to reduce the dimensionality of the matrices of abundance and species occurrence. We used the first three axes of the PCoAs as dependent variables in linear regression models (LM) to evaluate how the community structure is influenced by soil texture (clay content), fertility (the total exchangeable bases), slope, and HAND. The sum of bases and slope were log-transformed, and all predictor variables were standardized $($ mean $=0$; variance $=1$ ).

We evaluated the spatial autocorrelation of the dependent and predictor variables using Moran's I correlograms (Fortin \& Dale 2005), with the $P$-value calculated after 999 permutations. Autocorrelation in both dependent and predictor variables can bias significance tests, inflating type I errors (Legendre et al. 2002, Landeiro \& Magnusson 2011). When significant spatial autocorrelation was detected in at least one distance class (Bonferroni-corrected) for these variables, we evaluated the significance of the predictors using linear mixed-effects models (Zuur et al. 2009). In this modeling approach, a second random component representing the correlation structures among observations within transects (LME) was included, in addition to the fixed component (predictors) and error. Another mixed-effects model (SEM, spatially explicit model) included correlation structures (e.g., exponential, Gaussian, linear, quadratic or spherical) on the geographic coordinates of the plots (latitude and/or longitude), in addition to the random effect of transect. We used the Akaike Information Criterion (AIC; Burnham \& Anderson 2002) to select the best correlation structure in the spatially explicit model.

We used the likelihood ratio test (Zuur et al. 2009) to compare the mixed-effects models (LME, SME) and simple linear models (LM; fitted as generalized least squares for comparison). We also used this test to evaluate the partial significance of the predictor variables in mixed-effects models. We calculated the $\mathrm{R}^{2}$ marginal in mixed-effects models (the proportion of variance explained only by the fixed predictors; Nakagawa \& Schielzeth 2013). We conducted the analysis above using the lme function of the nlme package (Pinheiro et al. 2011) in the R environment (R Development Core Team 2012).

To understand how prone species are to the effects of the dam, we illustrated relationships between the environment and the 50 most abundant species that occur in the study area. The relative abundance of these species was plotted against environmental gradients formed by the predictor variables, the side of the Madeira River, and the area under direct or indirect influence of the reservoir.

We also evaluated the hierarchical importance of the effect of each environmental predictor on the patterns of community structure through multivariate regression trees (MRT; De'ath 2002) in each diameter class and for all classes, together. In each subset of quantitative data, we used PCoA axes that together captured at least 70 percent of the total variation in species data (Pansonato et al. 2013). Divisions in the MRTs were determined by cross-validation. We performed these analyses in the mvpart package for $\mathrm{R}$ (Therneau et al. 2013).

\section{RESULTS}

We sampled 8504 individuals belonging to 909 tree species/morphospecies (299 genera and 76 families; Table S1). The number of individuals per plot ranged between 219 and 674, and the species richness varied from 78 to 200. Most species sampled were rare: 63 percent were represented by five or fewer individuals, 32 percent by a single individual, and 43 percent occurred in a single plot. On the other hand, the 50 most abundant species accounted for 41 percent of all trees sampled.

Ordination diagrams of floristic composition (Fig. 1A-C) and community structure (Fig. 1D) of 20 forest plots are presented. The first three axes of the PCoA explained 43 percent of the total variation in species composition with occurrence data and 40 percent of the total variation with abundance data, considering all dbh classes together (Table 2). Plots were clustered with respect to the side of the Madeira River, especially in the abundance data (Fig. 1D). There was also a high degree of similarity among plots located in the same transect/sample module for both occurrence and abundance data (Fig. 1). Plots located in the area affected by the reservoir tended to group together but did not form a single cluster of points.

Most mixed-effects models accommodated the lack of independence between observations, resulting in a smaller bias compared to linear models (Table 2). However, the fits of the mixed-effects models (LME and SEM) were no better than their respective linear models, especially for the class of $\mathrm{dbh} \geq 30 \mathrm{~cm}$. In these cases, we were careful with the interpretations and inferences except for the linear model of abundance data (PCoA1), which was not affected by a lack of independence between observations. This model indicated the highest effect of sum of bases in the floristic composition of $\mathrm{dbh} \geq 30 \mathrm{~cm}$. The floristic structure (PCoA1 for all individuals) responded marginally to the sum of bases and HAND. Soil fertility was also the factor with the greatest effect on the $10-30 \mathrm{~cm}$ dbh class (PCoA1, abundance and occurrence data) (Table 2). Other ordination axes in this dbh class responded to variables such as HAND and clay. The structure and floristic composition of the understory $(1<\mathrm{dbh}<10 \mathrm{~cm})$ were mainly related to HAND, clay, and slope, but there was no effect of sum of bases (Table 2).

The gradient analysis of the floristic structure (summarized by the first axis of the PCoA for individuals with $\mathrm{dbh} \geq 30 \mathrm{~cm}$ ) as a function of the sum of bases, assuming average values for the remaining predictor variables, shows a strong association between floristic structure and soil fertility (Fig. 2). Groups of plots that were affected and unaffected by the reservoir displayed wide variation in their floristic structures and soil fertility.

With respect to the gradient analysis, soils with higher fertility occurred in plots located in sampling modules of the intermediate portion (Mutum) and at the end of the reservoir (Abunã) (Fig. 3). Furthermore, plots closer to the Madeira River (P1 plots) also showed higher values of sum of bases, and the three plots with the highest values were located in the flooding zone of the 

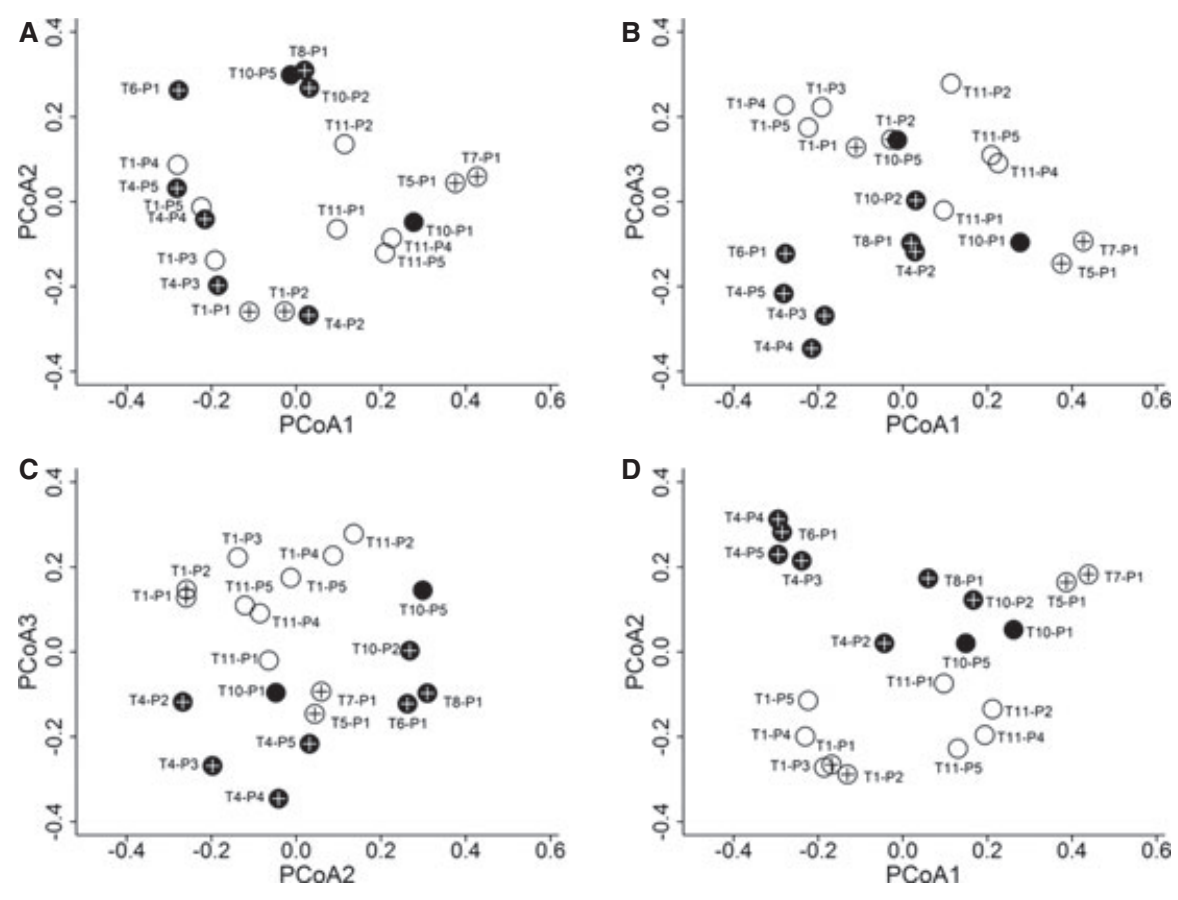

FIGURE 1. Ordination diagrams (PCoA) of 20 plots on the left ( $\mathrm{O})$ and right $(\bullet)$ sides (when facing downstream) of Madeira River, Southern Amazonia. Crosses represent plots affected by the Jirau reservoir. Results are based on presence/absence (A-C) and abundance (D) data.

reservoir (Fig. 3). Some species were more abundant in plots with lower fertility and in areas highly affected by the reservoir (Caiçara module T4). Species found in areas with higher fertility in Abunã and Mutum modules were more evenly distributed among study sites, occurring in plots affected and unaffected by the reservoir. (Fig. 3).

Soil texture did not seem to be strongly associated with abundance of common species (Fig. S2). With respect to slope gradient, a group of species showed higher abundance in flatter plots both in areas affected and unaffected by the reservoir, whereas a larger group of species occurred along the slope gradient (Fig. S3). With respect to the HAND variable, plots in the area of flooding had the lowest values, especially in the modules next to the dam (Caiçara) and in the intermediate portion (Mutum) (Fig. S4).

Differences in composition and structure between the communities located on the left and right sides of the river were observed when considering the occurrence of the 50 most abundant species. Species typical of terra firme-campinarana-várzea transitions were more abundant on the right side of the Madeira River (Fig. S5A).

When considering the 50 most abundant tree species, a comparative analysis of the areas affected and unaffected by the reservoir suggested differences in species abundances (Fig. S5B). Among all species/morphospecies sampled, 253 (28\%) were recorded only in plots affected by the UHE Jirau reservoir (species marked with an asterisk on Table S1).

Multivariate regression trees analyses indicated that the responses of floristic structure, summarized by PCoA axes, were predominant affected by soil fertility (Fig. 4). The first division of the MRT was produced by the sum of bases for all individuals and for each diameter class analyzed separately. In the class $\mathrm{dbh} \geq 30 \mathrm{~cm}$, the explanatory variable HAND is associated with a second division of the MRT.

\section{DISCUSSION}

The forests sampled in the area of the UHE Jirau are heterogeneous, and such differences are influenced mostly by soil fertility, with soil texture, slope and the vertical distance with respect to the nearest drainage playing a secondary role. Differences in species composition occurred throughout the reservoir area but were most pronounced between plots with dystrophic soils next to the damming and plots with more fertile soils in the middle and final portions of the reservoir. In addition, we observed marked differences between areas situated on the left and right sides of the Madeira River. The different soil types, geological formations and the influence of the riparian zone of the Madeira River contributed substantially to these patterns.

Multivariate regression trees (MRT) showed that the sum of bases was the best predictor to explain the variation in plant communities, reinforcing the results obtained using linear and mixed-effects models (including models accounting for spatial autocorrelation). Among the factors related to soil, cations are important for explaining the distribution of terra firme species in western Amazon (Ruokolainen et al. 2007, Coronado et al. 2009, Higgins et al. 2011) and also play a role in determining plant communities on dystrophic soils in central Amazonia (Bohlman 
TABLE 2. Standardized partial coefficients of the predictor variables included in the candidate models. $\mathrm{P}$-values of partial variables $(\mathrm{P} \leq 0.10 ; * \mathrm{P} \leq 0.05 ; * * \mathrm{P} \leq 0.01$; ***P $\leq 0.001), \mathrm{R}^{2}$ marginal and $\mathrm{P}-v$ alue of the final model (LM, linear model; LME, mixed-effect model with transect as a random-effects term; SEM, spatially explicit model) are shown.

\begin{tabular}{|c|c|c|c|c|c|c|c|c|c|}
\hline DBH class & Type of data & Ordination axis & Explained variance & Sum of Bases & Clay & Slope & HAND & $\mathrm{R}^{2} \operatorname{marg}$ & Final model \\
\hline & QT & PCoA2 & 0.12 & 0.05 & 0.01 & 0.00 & -0.02 & $0.06 * * *$ & SEM \\
\hline & \multirow[t]{2}{*}{ QL } & PCoA1 & 0.18 & 0.11 & 0.05 & $0.05^{* *}$ & -0.08 & $0.22 * *$ & LME \\
\hline & & PCoA2 & 0.13 & 0.06 & -0.08 & $-0.07 * *$ & 0.11 & 0.36 & LME \\
\hline & \multirow{2}{*}{ QT } & PCoA2 & 0.12 & 0.07 & $-0.06^{* *}$ & $-0.02 * *$ & $0.05 * *$ & $0.23^{* *}$ & SEM \\
\hline & & PCoA3 & 0.10 & 0.02 & 0.04 & $0.04 * *$ & $-0.07 * * *$ & $0.18^{* *}$ & LME \\
\hline & \multirow[t]{3}{*}{ QL } & PCoA1 & 0.17 & 0.07 & -0.06 & -0.01 & 0.01 & $0.21 * * *$ & LME \\
\hline & & PCoA2 & 0.12 & -0.09 & 0.04 & 0.01 & 0.02 & $0.24 * *$ & SEM \\
\hline & & PCoA3 & 0.10 & -0.05 & $-0.05^{* *}$ & $0.06 * * *$ & $0.05 * *$ & $0.20 * * *$ & LME \\
\hline & \multirow[t]{3}{*}{ QL } & PCoA1 & 0.21 & 0.16 & 0.03 & $0.05^{* *}$ & 0.01 & $0.30 * *$ & SEM \\
\hline & & PCoA2 & 0.16 & -0.02 & -0.03 & 0.03 & 0.04 & $0.06 * *$ & SEM \\
\hline & & PCoA3 & 0.11 & -0.05 & $0.13^{* * *}$ & -0.05 & $0.13 * * *$ & $0.59 * * *$ & LM \\
\hline \multirow[t]{6}{*}{$30 \mathrm{~cm}$} & \multirow[t]{3}{*}{ QT } & PCoA1 & 0.19 & $0.20 * * *$ & -0.01 & -0.07 & 0 & $0.63 * * *$ & $\mathrm{LM}$ \\
\hline & & PCoA2 & 0.15 & -0.02 & 0.03 & -0.01 & 0.02 & $0.08^{* *}$ & LME \\
\hline & & PCoA3 & 0.10 & $0.08 * *$ & $0.13^{* *}$ & $0.08 * *$ & -0.06 & $0.38 * *$ & $\mathrm{LM}$ \\
\hline & \multirow[t]{3}{*}{ QL } & PCoA1 & 0.20 & $0.20 * * *$ & -0.01 & -0.07 & 0.03 & $0.69 * * *$ & LM \\
\hline & & PCoA2 & 0.13 & 0.01 & -0.07 & -0.04 & $-0.13 * *$ & $0.47 * *$ & LM \\
\hline & & PCoA3 & 0.09 & -0.08 & -0.11 & -0.06 & 0.08 & 0.28 & LM \\
\hline
\end{tabular}

QT, quantitative (abundance) data; QL, qualitative (presence/absence) data.

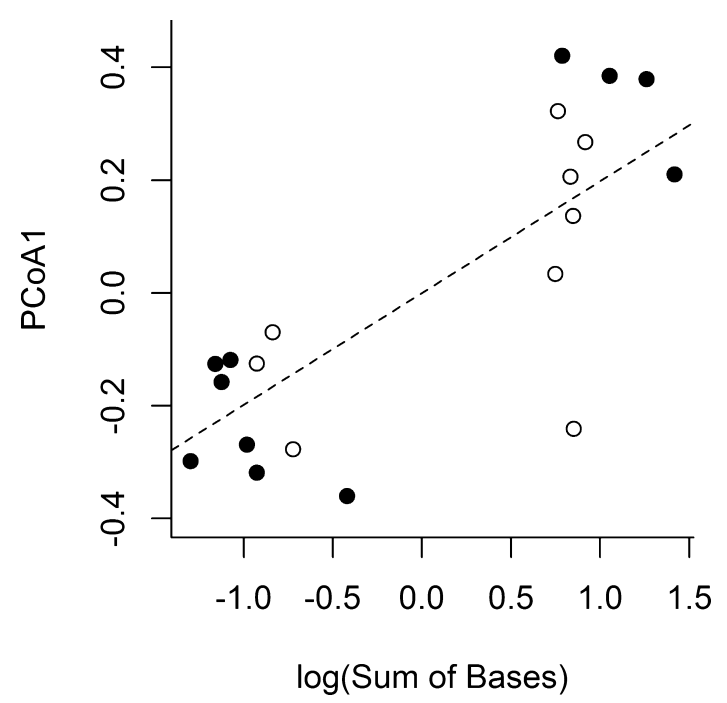

FIGURE 2. Linear model relating tree $(\mathrm{dbh} \geq 30 \mathrm{~cm})$ community structure (PCoA1) to the sum of bases. White and black dots represent plots affected and unaffected by the Jirau reservoir respectively. et al. 2008, Damasco et al. 2013). Soil texture, slope and, HAND were less important for explaining the variation in plant communities in the UHE Jirau plots, although HAND was associated with a secondary division in the MRT analysis for trees with $\mathrm{dbh}>30 \mathrm{~cm}$. Other studies have shown that when the length of soil fertility gradient is long (as in our study where the content of bases varied from 0.37 to more than $10 \mathrm{cmol} / \mathrm{dm}^{3}$ ), topography and soil texture tend to be less relevant to community structure, whereas in areas of homogeneously low fertility, topography, and texture become the main determinants of floristic patterns (Zuquim et al. 2012, Pansonato et al. 2013).

Forest species typical of plateau and slopes on latosols, such as Mabea angularis, Protium apiculatum, Mezilaurus itauba, Peltogyne paniculata, P. excelsa, and Rinorea guianensis (Ribeiro et al. 1999), characterized plots on latosols located on the left margins of the reservoir as typical terra firme forests. These species are associated with more hilly landscapes and well-drained soils. In the study area, geological formations are markedly different between the right and left sides of the Madeira River, and their influence on soil properties and topography determine the floristic differences observed. The right margin is characterized by a recent geological 


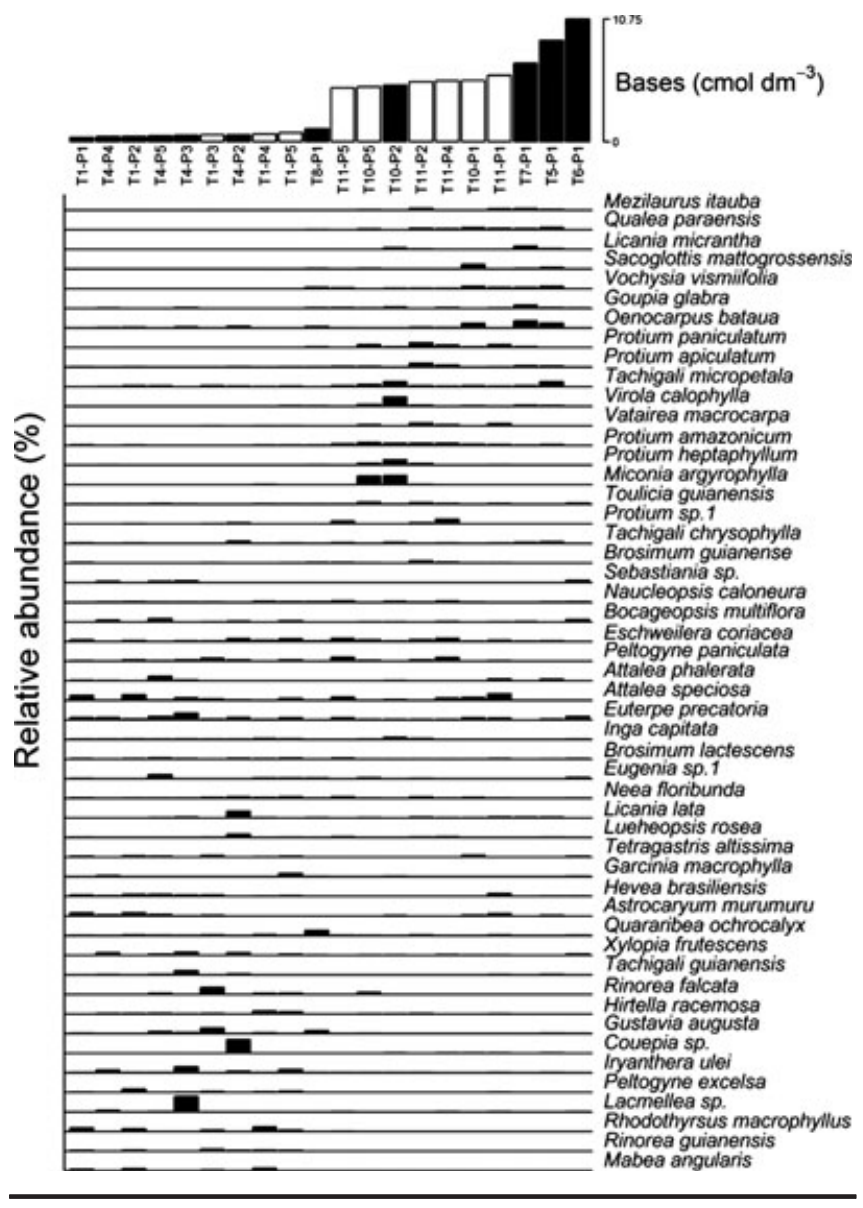

FIGURE 3. Distribution of 50 most abundant tree species along the gradient of base saturation in the soil. White and black bars represent plots affected and unaffected by the Jirau reservoir, respectively.

formation, with large alluvial deposits that extend from the dam to the final portion of the reservoir. On the left side, the predominant geological formation includes Proterozoic granitoids that are associated with a more hilly landscape and well-drained soils. The influence of edaphic and geological factors at the mesoscale found here corroborates the division of the Amazon region into floristic units based on such determinants (Higgins et al. 2011, Figueiredo et al. 2013).

Gleysols with fine texture and slow rates of decomposition of organic matter are relatively more fertile compared to adjacent soils in the Amazon (Quesada et al. 2010). The occurrence of transitional formations between terra firme and varzea and campinarana on the right side of the Madeira River, which are associated with Gleysols subject to seasonal flooding, contributed to the observed floristic and structural heterogeneity. Alluvial soils were also characteristic of plots that contained transitional formations between terra firme and varzea forests near the Madeira River in the intermediate and final portions of the reservoir. Due to the higher concentration of clay and cationic exchange capacity in alluvial substrates of Andean origin, varzea soils are richer in nutrients than the well-drained adjacent areas or floodplains of rivers of black water (igapó forests; Pires \& Prance 1985, Wittmann et al. 2010). The varzea forests harbor a highly specialized flora with morphological, physiological, and biochemical adaptations to seasonal flooding and anaerobic soil conditions (Wittmann et al. 2012). Although our plots were mostly restricted to terra firme forests, typical taxa of varzea and floodplains have been reported such as Astrocaryum murumuru, Oenocarpus batana, Euterpe precatoria, Iryanthera ulei, Attalea phalerata, and Virola calophylla (Henderson et al. 1995, Ribeiro et al. 1999, Wittmann et al. 2010). These species are particularly abundant in the area more directly affected by the Jirau reservoir, on the right margin on flatter terrains, suggesting that forest formations on the floodplains of the Madeira River have increased vulnerability. Amazonian floodplains are areas of major concern given the rising levels of threats imposed on such environments by the construction of new hydroelectric dams in the Amazon basin (Finer \& Jenkins 2012, Ferreira et al. 2013). Fortunately, most flood-tolerant varzea tree species are widespread across tropical America, and endemic species are not frequent (Wittmann et al. 2012).

An important question to be addressed from a plant conservation perspective is: how many species would be locally/regionally lost in the areas affected by the UHE Jirau reservoir? Although the number of species/morphospecies restricted to plots affected by the reservoir is somewhat large (255 species), the uncertainty related to a scenario of high-species richness combined with low species abundance (nearly a third of all species sampled are represented by a single tree) makes assessment of conservation risk a very complicated task. Our sampling effort is certainly not large enough to determine whether species that have only been recorded in plots affected by the reservoir are really restricted to that area in our study area, or if it is just an artifact of the naturally low tree species abundance in the Amazon (chance of sampling rare species is quite low). We consider the latter option the most plausible because the species that were only sampled in inundated plots were also likely to occur in areas not flooded by the UHE Jirau reservoir. The low abundance displayed by most species sampled here, and the fact that many of them are restricted to a single plot, are consistent with the overall pattern of rare tree species in the Amazon forest (ter Steege et al. 2013).

Most species sampled are widely distributed across the Amazon-although many of them may be locally rare (low abundance) - they are regionally widespread. None of the 603 species identified at the species level belonged to the 46 plant species reported as endemic to Rondônia in the Brazilian Flora Check-list ( \http://floradobrasil.jbrj.gov.br). Therefore, our results suggest that some species will be affected at a local scale (taking into account all the uncertainties regarding tree species densities and habitat preferences in the study area) but with a limited regional impact given that the vast majority of species recorded in plots affected by the UHE Jirau reservoir have a widespread distribution. Regardless, conservation measures are required in order to preserve species associations and ecosystems processes similar to those most affected by the Madeira River hydroelectric dams.

The building of hydroelectric dams in the Amazon is controversial, and requires a trade-off between the rising demand for electricity and the urgency of conservation efforts in a region of 


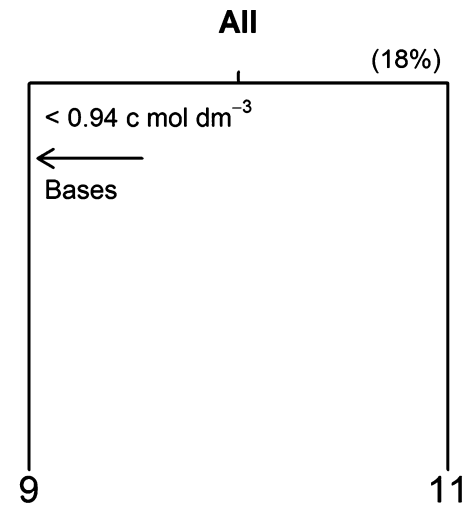

8 axes

Error: 0.820

\section{DBH $10-30 \mathrm{~cm}$}

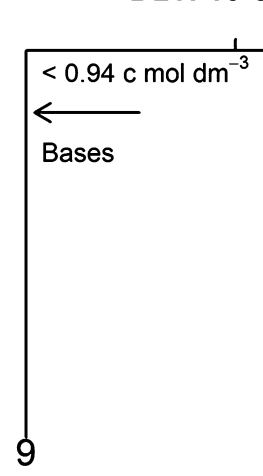

7 axes

Error: 0.812
DBH 1-10 cm
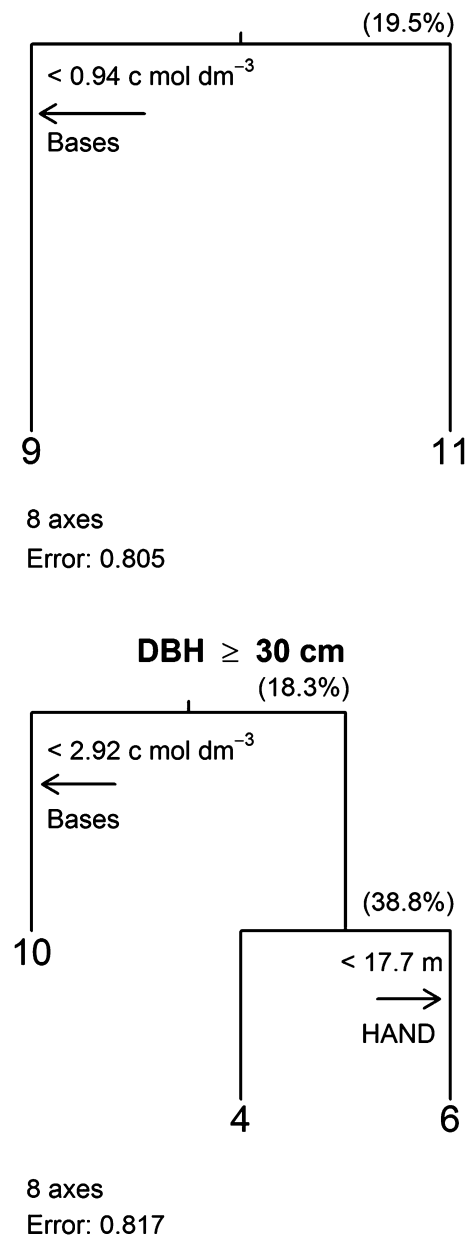

FIGURE 4. Multivariate regression trees (MRT) for the entire tree community and separate analyses by diameter classes (dbh). The values at the end of the branches represent the number of plots. The percentage of improvement gained from each division is reported in parentheses. The number of PCoA axes required to cover at least 70 percent of the variance explained, which were used as dependent variables, and the error variance not explained by the MRT, are shown at the botton of each diagram.

remarkably rich biodiversity. Our study reinforces the need for considering the heterogeneity of habitats affected by hydroelectric reservoirs, as well as the complex responses of the vegetation to flooding, when making decisions concerning the building of hydroelectric dams.

\section{ACKNOWLEDGMENTS}

We thank Antonio José Barreto dos Santos (Tonico), Ednéia Santos, Evandro Ferreira, Gledson Alves Moreira, Valdeci Ferreira Gomes, Aécio Amaral, Nilton Ferreira, Juarez Amaral, Natalia Perigolo, Márcio Honorato, Samanta Gianni, Victor Vinicius Ferreira Lima, João Benedito Pereira, Bernardo Teixeira, Rachel Camargo, Sérgio Eustáquio Noronha, Bruno Walter, Gabriela Ribeiro Silva, Marco Canedo and Jairo Guerrero, in addition to ESBR-Energia Sustentável do Brasil and Fundação Eliseu Alves. JRRP acknowledges the National Council of Technological and Scientific Development $(\mathrm{CNPq})$ for a Productivity Research
(PQ) scholarship. This article is part of the first author's Masters dissertation (University of Braslia) supported by a scholarship from the Reuni Programme.

\section{SUPPORTING INFORMATION}

Additional Supporting Information may be found in the online version of this article:

FIGURE S1. Location of modules for sampling of arboreal vegetation in open rain forests on the right and left sides (when facing downstream) of the Madeira River, along the area of influence of the reservoir of the Jirau hydroelectric reservoir in Rondônia, Brazil.

FIGURE S2. Distribution of the 50 most abundant tree species along the gradient of soil texture.

FIGURE S3. Distribution of the 50 most abundant tree species along the gradient of slope. 
FIGURE S4. Distribution of the 50 most abundant tree species along the gradient of the height above the nearest drainage-HAND.

FIGURE S5. Distribution of 50 most abundant tree species on the left and right margins (when facing downstream) of the Madeira River and in the area affected and unaffected by the Jirau reservoir.

TABLE S1. Species/morphospecies sampled in 20 1-hectare forest plots located in the area of the UHE Jirau, Rondônia, Brazil.

\section{LITERATURE CITED}

Bohlman, S. A., W. F. Laurance, S. G. Laurance, H. E. M. Nascimento, P. M. Fearnside, and A. Andrade. 2008. Importance of soils, topography and geographic distance in structuring central Amazonian tree communities. J. Veg. Sci. 19: 863-874.

Burnham, K. P., and D. R. Anderson. 2002. Model selection and multimodel inference: A practical information-theoretic approach. 2nd edn. Springer-Verlag, New York.

Cochrane, T. T., And T. A. Cochrane. 2010. Amazon Forest and Savanna Lands: A guide to the climates, vegetation, landscapes, and soils of Central Tropical South America. CreateSpace Independent Publishing Platform, Seattle, WA.

Condit, R., N. Pitman, E. G. Leigh, J. Chave, J. Terborgh, R. B. Foster, P. Núñez, S. Aguilar, R. Valencia, G. Villa, H. C. Muller-Landau, E. Losos, AND S. P. HubBell. 2002. Beta-diversity in tropical forest trees. Science 295: 666-669.

Coronado, H. E. N., T. R. Baker, O. L. Phillips, N. C. A. Pitman, R. T. Pennington, R. Vásquez Martínez, A. Monteagudo, H. Mogollón, N. Dávila Cardozo, M. Ríos, R. García-Villacorta, E. Valderrama, M. Ahuite, I. Huamantupa, D. A. Neill, W. F. LauRance, H. E. M. Nascimento, S. Soares de Almeida, T. J. Killeen, L. Arroyo, P. Núñez, and L. Freitas Alvarado. 2009. Multi-scale comparisons of tree composition in Amazonian terra firme forests. Biogeosciences 6: 2719-2731.

Costa, F. R. C., J.-L. Guillaumet, A. P. Lima, and O. S. Pereira. 2009. Gradients within gradients: the mesoscale distribution patterns of palms in a central Amazonian forest. J. Veg. Sci. 20: 69-78.

Costa, F. R. C., W. E. Magnusson, and R. C. Luizao. 2005. Mesoscale distribution patterns of Amazonian understorey herbs in relation to topography, soil and watersheds. J. Ecol. 93: 863-878.

CPRM. 2004. Carta Geológica do Brasil ao Milionésimo, Sistema de Informações Geográficas. Serviço Geológico do Brasil, Brasılia, Brazil.

Damasco, G., A. Vicentini, C. V. Castilho, T. P. Pimentel, and H. E. M. NAscimento. 2013. Disentangling the role of edaphic variability, flooding regime and topography of Amazonian white-sand vegetation. J. Veg. Sci. 24: 384-394.

De'ATH, G. 2002. Multivariate regression trees: a new technique for modeling species-environment relationships. Ecology 83: 1105-1117.

Dexter, K. G., J. W. Terborgh, and C. W. Cunningham. 2012. Historical effects on beta diversity and community assembly in Amazonian trees. Proc. Natl. Acad. USA 109: 7787-7792.

Drucker, D. P., F. R. C. Costa, And W. E. Magnusson. 2008. How wide is the riparian zone of small streams in tropical forests? A test with terrestrial herbs. J. Trop. Ecol. 24: 65-74.

Fearnside, P. M. 2013. Decision-making on Amazon dams: Politics trumps uncertainty in the Madeira River sediments controversy. Water Alternat. 6: 313-325.

Ferraz, S. F. D. B., C. A. Vettorazzi, D. M. Theobald, and M. V. R. BalLESTER. 2005. Landscape dynamics of Amazonian deforestation between 1984 and 2002 in central Rondônia, Brazil: Assessment and future scenarios. Forest Ecol. Manag.. 204: 69-85.
Ferreira, L. V. 2000. Effects of flooding duration on species richness, floristic composition and forest structure in river margin habitat in Amazonian blackwater floodplain forests: Implications for future design of protected areas. Biodivers. Conserv. 9: 1-14.

Ferreira, L. V., D. A. Cunha, D. C. Leal, and P. P. Chaves. 2013. Impacts of the hydroelectric dams in the endemic plant communities of floodplains of the Tapajós, Xingu and Tocantins Rivers in Eastern Amazonian. Acad. Bras. Ciênc. 85: 241-251.

Ferreira, L. V., and G. T. Prance. 1998. Species richness and floristic composition in four hectares in the Jaú National Park in upland forests in Central Amazonia. Biodivers. Conserv. 7: 1349-1364.

Figueiredo, F. O. G., F. R. C. Costa, B. W. Nelson, and T. P. Pimentel. 2013. Validanting Forest type based on geological and land-form features in Central Amazonia. J. Veg. Sci. 24: 1-15.

Finer, M., And C. N. Jenkins. 2012. Proliferation of hydroelectric dams in the Andean Amazon and implications for Andes-Amazon connectivity. PLoS ONE 7: e35126.

Fortin, M. J., AND M. R. T. Dale. 2005. Spatial analysis [electronic resource]: a guide for ecologists. Cambridge University Press, Cambridge.

Henderson, A., G. Galeano, and R. Bernal. 1995. Field Guide to the Palms of the Americas. Princeton University Press, Princeton, New Jersey.

Higgins, M. A., K. Ruokolainen, H. Tuomisto, N. Llerena, G. Cardenas, O. L. Phildips, R. VÁsquez, and M. RÄsÄnen. 2011. Geological control of floristic composition in Amazonian forests. J. Biogeog. 38: 2136-2149.

IBGE. 2004. Mapa de Vegetação do Brasil. 3 ed. Available at $\backslash$ ftp://ftp.ibge. gov.br/cartas_e_mapas/mapas_murais/ (accessed 8 August 2013).

INMET. 2013. Normais Climatológicas - dados de 1961 a 1990. Available at: \http://www.inmet.gov.br/ (accessed 3 April 2013).

Kinupp, V. F., AND W. E. Magnusson. 2005. Spatial patterns in the understorey shrub genus Psychotria in central Amazonia: Effects of distance and topography. J. Trop. Ecol. 21: 363-374.

Landeiro, V. L., And W. E. Magnusson. 2011. The geometry of spatial analyses: Implications for conservation biologists. Nat. Conserv. 9: 7-20.

Legendre, P., M. R. T. Dale, M.-J. Fortin, J. Gurevitch, M. Hohn, and D. MYers. 2002. The consequences of spatial structure for the design and analysis of ecological field surveys. Ecography 25: 601-615.

Magnusson, W. E., A. P. Lima, R. Luizão, F. Luizão, F. R. C. Costa, C. V. D. Castilho, and V. F. Kinupr. 2005. RAPELD: A modification of the Gentry method for biodiversity surveys in long-term ecological research sites. Biota Neotrop. 5: 19-24.

NAKAgawa, S., AND H. Schielzeth. 2013. A general and simple method for obtaining $\mathrm{R}^{2}$ from generalized linear mixed-effects models. Methods Ecol. Evol. 4: 133-142.

Nobre, A. D., L. A. Cuartas, M. Hodnett, C. D. Rennó, G. Rodrigues, A. Silveira, M. Waterloo, and S. Saleska. 2011. Height above the nearest drainage - a hydrologically relavant new terrain model. J. Hydrol. 404: 13-29.

Pansonato, M. P., F. R. C. Costa, C. V. de Castilho, F. A. Carvalho, and G. Zuquim. 2013. Spatial Scale or amplitude of predictors as determinants of the relative importance of environmental factors to plant community structure. Biotropica 45: 299-307.

Phillips, O. L., P. N. Vargas, A. L. Monteagudo, A. P. Cruz, M.-E. C. Zans, W. G. SÁnchez, M. Yli-Halla, and S. Rose. 2003. Habitat association among Amazonian tree species: A landscape-scale approach. J. Ecol. 91: 757-775.

Pinheiro, J., D. Bates, S. Debroy, and D. Sarkar, and R Development Core Team. 2011. nlme: Linear and nonlinear mixed effects models. R package version 3.1-100, Vienna, Austria.

Pires, J. M., and G. T. Prance. 1985. The vegetation types of the Brazilian Amazon. In G. T. Prance and T. E. Lovejoy (Eds.). Amazonia Key Environment, pp. 109-145. Pergamon Press, London, UK.

Pitman, N. C. A., H. Mogollón, N. Dávila, M. Ríos, R. García-Villacorta, J. Guevara, T. R. Baker, A. Monteagudo, O. L. Phillips, R. Vás- 
quez-Martínez, M. Ahuite, M. Aulestia, D. Cardenas, C. E. Cerón, P.-A. Loizeau, D. A. Neill, P. Núñez V, W. A. Palacios, R. SpichiGer, And E. Valderrama. 2008. Tree community change across $700 \mathrm{~km}$ of Lowland Amazonian forest from the Andean Foothills to Brazil. Biotropica 40: 525-535.

ter steege, H., N. Pitman, O. L. Phillips, J. Chave, D. Sabatier, A. Duque, J.-F. Molino, M.-F. Prevost, R. Spichiger, H. Castellanos, P. Von HILDEBRAND, AND R. VASQUEz. 2006. Continental scale patterns of canopy tree composition and function across Amazonia. Nature 44: 444 447.

Quesada, C. A., J. Lloyd, M. Schwarz, S. Patiño, T. R. Baker, C. Czimczik, N. M. Fyllas, L. Martinelli, G. B. Nardoto, J. Schmerler, A. J. B. Santos, M. G. Hodnett, R. Herrera, F. J. Luizão, A. Arneth, G. Lloyd, N. Dezzeo, I. Hilke, I. Kuhlmann, M. Raessler, W. A. Brand, H. Geilmann, J. O. Moraes Filho, F. P. Carvalho, R. N. Araujo Filho, J. E. Chaves, O. F. Cruz Junior, T. P. Pimentel, and R. PAIVA. 2010. Variations in chemical and physical properties of Amazon forest soils in relation to their genesis. Biogeosciences 7: 1515-1541.

R Development Core Team. 2012. R: A language and environment for statistical computing. R Foundation for Statistical Computing, Vienna, Austria.

Ribeiro, J. E. L. S., M. J. G. Hopkins, A. Vicentini, C. A. Sothers, M. A. S. Costa, J. M. Brito, M. A. D. Souza, L. H. P. Martins, L. G. Lohmann, P. A. C. L. Assunção, E. C. Pereira, C. F. Silva, M. R. MesQuita, And L. C. Procópio. 1999. Flora da Reserva Ducke: Guia de Identificação das Plantas Vasculares de uma Floresta de Terra-Firme na Amazônia Central. Instituto Nacional de Pesquisas da Amazônia/ DFID, Manaus, Brazil.

Ruokolainen, K., H. Tuomisto, M. J. Macía, M. A. Higgins, and M. YuHaLLA. 2007. Are floristic and edaphic patterns in Amazonian rain forests congruent for trees, pteridophytes and Melastomataceae? J. Trop. Ecol. 23: 13-25.

Santos, H. G. D., W. Carvalho Júnior, R. O. Dart, M. L. D. Áglio, J. S. Sousa, J. G. Pares, A. Fontana, A. L. S. Martins, and A. P. OlineIRA. 2011. O novo mapa de solos do Brasil legenda atualizada. Embrapa Solos, Rio de Janeiro, Brazil.

Schietti, J., E. Thaise, C. Rennó, D. P. Drucker, F. R. C. Costa, A. Nogueira, F. B. Baccaro, F. Figueiredo, C. V. Castilho, V. Kinupp, J. L. Guillaumet, A. R. Garcia, A. P. Lima, and W. E. Magnusson. 2013. Vertical distance from drainage drives floristic composition changes in an Amazonian rainforest. Plant Ecol. Divers. v.online 1-10.

ter Steege, H., N. C. A. Pitman, D. Sabatier, C. Baraloto, R. P. Salomão, J. E. Guevara, O. L. Phillips, C. V. Castilho, W. E. Magnusson, J.-F. Molino, A. Monteagudo, P. Núñez Vargas, J. C. Montero, T. R. Feldpausch, E. N. H. Coronado, T. J. Killeen, B. Mostacedo, R. Vasquez, R. L. Assis, J. Terborgh, F. Wittmann, A. Andrade, W. F. Laurance, S. G. W. Laurance, B. S. Marimon, B.H. Marimon, I. C. Guimarães Vieira, I. L. Amaral, R. Brienen, H. Castellanos, D. Cárdenas López, J. F. Duivenvoorden, H. F. Mogollón, F. D. D. A. Matos, N. Dávila, R. García-Villlacorta,
P. R. Stevenson Diaz, F. Costa, T. Emilio, C. Levis, J. Schietti, P. Souza, A. Alonso, F. Dallmeier, A. J. D. Montoya, M. T. Fernandez Piedade, A. Araujo-Murakami, L. Arroyo, R. Gribel, P. V. A. Fine, C. A. Peres, M. Toledo, G. A. Aymard C, T. R. Baker, C. Cerón, J. Engel, T. W. Henkel, P. Maas, P. Petronelli, J. Stropp, C. E. Zartman, D. Daly, D. Neill, M. Silveira, M. R. Paredes, J. Chave, D. D. A. Lima Filho, P. M. Jørgensen, A. Fuentes, J. Schöngart, F. Cornejo Valverde, A. Di Fiore, E. M. Jimenez, M. C. Peñuela Mora, J. F. Phillips, G. Rivas, T. R. van Andel, P. von Hildebrand, B. Hoffman, E. L. Zent, Y. Malhi, A. Prieto, A. Rudas, A. R. Ruschell, N. Silva, V. Vos, S. Zent, A. A. Oliveira, A. C. Schutz, T. Gonzales, M. Trindade Nascimento, H. RAmirez-Angulo, R. Sierra, M. Tirado, M. N. Umaña Medina, G. van der Heijden, C. I. A. Vela, E. Vilanova Torre, C. Vriesendorp, O. Wang, K. R. Young, C. Baider, H. Balslev, C. Ferreira, I. Mesones, A. Torres-Lezama, L. E. Urrego Giraldo, R. Zagt, M. N. Alexiades, L. Hernandez, I. Huamantupa-Chuquimaco, W. Milliken, W. Palacios Cuenca, D. Pauletto, E. Valderrama Sandoval, L. Valenzuela Gamarra, K. G. Dexter, K. Feeley, G. Lopez-Gonzalez, And M. R. Silman. 2013. Hyperdominance in the Amazonian tree flora. Science 342: 325-334.

Terborgh, J., and E. Andresen. 1998. The composition of Amazonian forests: Patterns at local and regional scales. J. Trop. Ecol. 14: 645-664.

Therneau, T. M., B. Atkinson, B. Ripley, J. Jari Oksanen, and G. De’ath. 2013. mvpart: Multivariate partitioning. $R$ package version 1.6-1. Available at:// \http://CRAN.R-project.org/package=mvpart/ (accessed 10 September 2013).

Toledo, M., L. Poorter, M. Peña-Claros, A. Alarcón, J. Balcázar, J. Chuviña, C. Leaño, J. C. Licona, H. ter Steege, and F. Bongers. 2011. Patterns and determinants of floristic variation across lowland forests of Bolivia. Biotropica 43: 405-413.

Tuomisto, H., K. Ruokolainen, A. D. Poulsen, R. C. Moran, C. Quintana, G. Cañas, and J. Celi. 2002. Distribution and diversity of Pteridophytes and Melastomataceae along edaphic gradients in Yasuní National Park, Ecuadorian Amazonia. Biotropica 34: 516-533.

Wittmann, F., E. Householder, M. T. F. Piedade, R. L. de Assis, J. Schön. Gart, P. Parolin, and W. J. Junk. 2012. Habitat specifity, endemism and the neotropical distribution of Amazonian white-water floodplain trees. Ecography 35: 1-18.

Wittmann, F., J. Schongart, J. M. Brito, A. O. Wittmann, M. T. F. Piedade, P. Parolin, W. J. Junk, and J. L. Guillaumet. 2010. Manual of trees from central Amazonian várzea floodplains. Inpa, Manaus, Brazil.

Zuquim, G., H. Tuomisto, F. R. C. Costa, J. Prado, W. E. Magnusson, T. PImentel, R. Braga-Neto, and F. O. G. Figueiredo. 2012. Broad scale distribution of ferns and lycophytes along environmental gradients in Central and Northern Amazonia, Brazil. Biotropica 44: 752-762.

Zuur, A. F., E. N. Ieno, N. J. Walker, A. A. Saveliev, and G. M. Smith. 2009. Mixed effects models and extensions in ecology with R. Springer Verlag, New York. 